DOI: $10.14720 /$ aas.2016.107.1.10

Agrovoc descriptors: biological control; biological control agents; zea mays; maize; plant pests; ostrinia nubilalis; ichneumonidae; insect pests; parasitoids

Agris category code: $\mathrm{H} 10, \mathrm{~h} 01$

\title{
Parasitoid inventarisation of European corn borer (Ostrinia nubilalis Hübner, 1796) and options for its biological control in Slovenia
}

\author{
Jaka RAZINGER ${ }^{1}$, Špela MODIC ${ }^{2}$, Annette HERZ $^{3}$, Gregor UREK ${ }^{4}$
}

Received October 08, 2015; accepted Janury 21, 2016.

Delo je prispelo 08. oktobra 2015, sprejeto 21. januarja 2016.

\begin{abstract}
European corn borer (Ostrinia nubilalis) (ECB) is an important maize pest in central and northern Europe. Presently it is controlled by insecticides or biological agents such as Trichogramma brassicae in several European countries, excluding Slovenia, where the pest's pressure is highly variable and no appropriate mechanization is available. Lessening the dependence on chemical pesticides is an integral part of the European Union's agenda for agriculture. Mass release of Trichogramma spp. could be seen as a promising alternative for ECB control in countries with a highly fluctuating ECB pressure and no mechanization for insecticide applications. However, no records of naturally occurring hymenopteran parasitoids of ECB exist in Slovenia. To address this important under-researched topic and provide the expert basis for potential introduction of ECB egg parasitoids in Slovene maize production, a systematic inventarisation programme of ECB parasitoids was launched in 2010. Additionally, ECB flight was monitored in 2011 and 2012 at two locations in Slovenia: Jablje and Rakičan. In both locations two ECB generations were observed. ECB was fist observed at the end of May in Rakičan. During the five years of the systematic survey we discovered two ECB parasitoid species. ECB egg masses were parasitized by Trichogramma brassicae, whereas ECB pupae were parasitized by Tycherus nigridens, with 6 or $7 \%$ parasitation rate, respectively. T. nigridens represents a new taxon report for Slovenia. We conclude that there is a strong need for undertaking systematic surveys of natural enemies of agricultural pests.
\end{abstract}

Key words: biological control; corn; Ichneumonidae; insect pests; maize; new records; parasitoids; Tycherus nigridens; Trichogrammatidae; Trichogramma brassicae; Zea mays

\section{IZVLEČEK}

\author{
INVENTARIZACIJA PARAZITOIDOV KORUZNE VEŠČE \\ (Ostrinia nubilalis Hübner, 1796) IN MOŽNOSTI NJENEGA \\ BIOTIČNEGA ZATIRANJA V SLOVENIJI
}

Koruzna vešča (Ostrinia nubilalis) (ECB) je pomemben škodljivec koruze $\mathrm{v}$ srednji in severni Evropi. V številnih evropskih državah jo obvladujejo z insekticidi, kar pa ne velja za Slovenijo, saj poleg tega, da je populacijski pritisk tega škodljivca zelo spremenljiv oziroma nepredvidljiv, tudi ni na voljo ustrezne škropilne tehnike. Glede na zastavljene cilje EU, ki so usmerjeni v zmanjševanje tveganja zaradi rabe fitofarmacevtskih sredstev, je uporaba biotičnih agensov, kot je na primer množični izpust parazitoidov iz rodu Trichogramma proti ECB dobrodošla in obetavna alternativa kemičnim sredstvom. Znanje o zastopanosti in razširjenosti parazitoidov ECB iz reda kožekrilcev je $\mathrm{v}$ Sloveniji še vedno pomanjkljivo. Za preučitev možnosti obvladovanja ECB z biotičnimi agensi smo leta 2010 začeli sistematično spremljati navzočnost in razširjenost parazitoidov ECB na koruznih poljih. Dodatno smo v letih 2011 in 2012 spremljali nalet ECB v Jabljah in Rakičanu. Na obeh lokacijah smo odkrili dva rodova ECB. Škodljivec se je navadno pojavil najprej $\mathrm{v}$ Rakičanu konec maja. $\mathrm{V}$ petih letih raziskave smo $\mathrm{v}$ Sloveniji naleteli na dve vrsti parazitoidov ECB, in sicer na vrsto Trichogramma brassicae, ki smo jo izolirali iz parazitiranih jajčec ECB in na vrsto Tycherus nigridens, ki smo jo izolirali iz parazitiranih bub ECB. Stopnja parazitizma je bila $6 \%$ za $T$. brassicae in $7 \%$ za $T$. nigridens. Vrsta T. nigridens predstavlja novo taksonomsko najdbo za Slovenijo. Zaključujemo, da je izvajanje sistematičnega iskanja in inventarizacije naravnih sovražnikov kmetijskih škodljivcev nujnega pomena za Slovenijo.

Ključne besede: biotično varstvo; Ichneumonidae; koruza; nove najdbe; parazitoidi; Tycherus nigridens; škodljivci koruze; Trichogrammatidae; Trichogramma brassicae; Zea mays

\footnotetext{
1 PhD, Agricultural Institute of Slovenia, Hacquetova ulica 17, Ljubljana, Slovenia. Tel.: (+386) 12805 117; fax: (+386) 1 2805 255; e-mail: jaka.razinger@kis.si

2 M.Sc., Agricultural Institute of Slovenia, Hacquetova ulica 17, Ljubljana, Slovenia

3 Julius Kühn Institute of Biological Control, Darmstadt, Germany

$4 \mathrm{PhD}$, Agricultural Institute of Slovenia, Hacquetova ulica 17, Ljubljana, Slovenia
} 


\section{INTRODUCTION}

Corn borers represent an important biotic stressor for maize (Zea mays L.) crops in Europe (Meissle et al., 2010). European corn borer (Ostrinia nubilalis (Hübner 1796)) (ECB) is the most important maize pest in central and northern Europe, while pink stem borer (Sesamia nonagrioides (Lef., 1827) is predominant in warmer areas of southern Europe (Velasco et al., 2002; Malvar et al., 2004; Meissle et al., 2010). ECB mostly causes damage by larvae that enter into the maize stalk after hatching and feed on the stalk pith. Yield is affected by ECB tunnelling which interferes with vascular system and increases the risk of stalk lodging and breakage (Gomboc et al., 1999). In addition, corn borer damage can affect plant health by vectoring Fusarium moniliforme J. Sheld. and facilitating fungal infections (Sobek and Munkvold, 1999). The yield loss produced by corn borer attack of the ear is sometimes less important than yield reduction associated to stalk tunnelling, as this kind of damage has been described as an important factor for favouring high levels of fumonisins in maize kernels (Sobek and Munkvold, 1999; Butrón et al., 2009).

Foliar insecticide applications in maize production are used in most European regions (i.e. Spain, Hungary, Poland, Germany, Italy, France and Denmark). The most commonly used active ingredients are pyrethroids and organophosphates (Meissle et al., 2010). However, Pons and Albajes's (2002) results illustrate how broad spectrum insecticides can have undesirable effects regarding ECB control: although treating maize seeds with imidacloprid reduced the incidence of cutworms (Agrotis segetum Denis \& Schiffermüller, 1775), wireworms (Agriotes lineatus Linnaeus, 1767), pink stem borer and leafhoppers (Zyginidia scutellaris HerrichSchäffer, 1838), treated plots were attacked significantly more by ECB. In Slovenia however, chemical measures in corn crops are not undertaken against ECB, partly due to highly fluctuating ECB pressure, partly due to nonexistent spraying mechanization. It is important to mention that ECB in Slovenia occurs also in vegetables like tomato, peppers and others, where the pest can be controlled with insecticides (Carlevaris et al., 2003).

Lessening the dependence on chemical pesticides is an integral part of the European Union's (EU) agenda for agriculture (European Parliament, 2009). The objective of this Directive is to reduce dependence on, as well as the risks and adverse impacts of, pesticide use on human health and the environment, and a key element to reach this goal is to promote the implementation of Integrated Pest Management (IPM), which has become compulsory in the EU in 2014. In sync with this directive and the previously mentioned reasons mass release of Trichogramma spp. is a promising alternative for ECB control in countries with a highly fluctuating ECB pressure and no insecticide applications. In Europe, the parasitoid wasps are already released mainly against ECB on about 150 000 ha per year with the largest area in France (Meissle et al., 2010). Encouraging results of biological control of ECB also exist from Asia (Zhang et al., 2010) and North America (Hoffmann et al., 2002; Hoffmann et al., 2006). An important ECB parasitoid, Trichogramma brassicae Bezdenko, 1968, was only recently discovered in Slovenia by Bohinc et al., (2015).

Despite encouraging results of biological control of $\mathrm{ECB}$, records of naturally occurring hymenopteran parasitoids of ECB in Slovenia are limited. To address this important under-researched topic and provide the expert basis for potential introduction of ECB egg parasitoids in Slovene maize production, a systematic inventarisation programme of ECB parasitoids was launched in 2010. In this paper we report the first findings.

\section{MATERIALS AND METHODS}

\subsection{Locations}

From 2010 to 2014 a systematic search for natural enemies of ECB was carried out at different locations in central Slovenia (Jablje near Ljubljana) and the north-eastern part of Slovenia (Rakičan, Prekmurje) with predominant maize 
production. Several fields within Agricultural Institute's Jablje experimental station were monitored $\quad\left(46^{\circ} 08^{\prime} 17.1^{\prime \prime} \mathrm{N}, \quad 14^{\circ} 34^{\prime} 15.2^{\prime \prime} \mathrm{E}\right.$

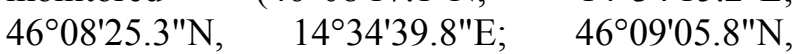
$14^{\circ} 34^{\prime} 52.5^{\prime \prime} \mathrm{E}$ and $\left.46^{\circ} 08^{\prime} 20.6^{\prime \prime} \mathrm{N}, 14^{\circ} 34^{\prime} 15.0^{\prime \prime} \mathrm{E}\right)$ and two locations near the Biotechnical School Rakičan $\quad\left(46^{\circ} 38^{\prime} 53.2^{\prime \prime} \mathrm{N}, \quad 16^{\circ} 13^{\prime} 21.3^{\prime \prime} \mathrm{E}\right.$ and $\left.46^{\circ} 39^{\prime} 17.1^{\prime \prime} \mathrm{N}, 16^{\circ} 11^{\prime} 33.1 " \mathrm{E}\right)$. The exact parasitoid finding dates are listed in Table 1.

Table 1: Dates and locations of parasitoid discoveries in the years 2010-2014

\begin{tabular}{|c|c|c|c|c|c|c|}
\hline \multirow[b]{2}{*}{ Year } & \multicolumn{3}{|c|}{ Jablje } & \multicolumn{3}{|c|}{ Rakičan } \\
\hline & T. brassicae & T. nigridens & Maize plants surveyed & T. brassicae & T. nigridens & Maize plants surveyed \\
\hline 2010 & 1 & 1 & 200 & 1 & / & 1 \\
\hline 2011 & Jul. 8 & Aug. 3 & 770 & Jul. 7 and Aug. 1 & I & 760 \\
\hline 2012 & Aug. 7. and Aug. 21 & I & 520 & 1 & Avg. 21 & 320 \\
\hline 2013 & 1 & / & 400 & / & / & l \\
\hline 2014 & 1 & 1 & 400 & l & 1 & 1 \\
\hline
\end{tabular}

\subsection{ECB flight monitoring}

In the sampled areas (Jablje, Rakičan) ECB flight was monitored with a fluorescent light trap (Grote Lichtval zonder lamp, Entomologie-speciaalzaak, Vermandel, Hulst, Nederlands) from May to September in the years 2011-2012. One trap per location was used.

\subsection{Scouting for ECB egg masses and pupae in the field}

Our search for natural enemies of ECB was focused on egg and pupal parasitoids. Search for ECB egg parasitoids was performed by scouting for ECB egg masses on the abaxial side of maize leaves. Scoutings were carried out during the oviposition period of the second ECB flight. All potentially parasitized ECB egg masses were collected and transferred to the entomological laboratory of Agricultural Institute of Slovenia for observation of parasitoid emergence. Pupal parasitoids were searched for in plants with evident ECB damage (stalk tunnelling and breakage, frass on leaves, holes in leaves). ECB damaged plants were dissected to collect ECB pupae, which were also transferred to the entomological laboratory of Agricultural Institute of Slovenia for observation of pupal parasitoid emergence.

\subsection{Observation of ECB egg masses and pupae for parasitoid emergence}

ECB egg masses on $10 \mathrm{~cm}^{2}$ pieces of maize leaves and ECB pupae were put into individual $50 \mathrm{~mL}$ centrifuge tubes. The tubes were kept at room temperature for observation until ECB larva/imago or parasitoid emerged.

\subsection{Parasitoid classification}

The morphological classification of the ECB egg mass parasitoids was based on Cônsoli et al. (2010), Ferriere and Kerrich (1958), Goulet and Huber (1993) to family and genus level. For species identification, Pintureau (2011) was used. Identification of Trichogramma species relies very heavily on examination of the male genitalia and to a lesser extent the male antennae. For this reason a slide-mounting technique modified from Platner et al. (1999) was necessary to allow the examination of male genitalia. Therefore, freshly emerged individuals of the egg parasitoid were killed and incubated in $90 \%$ lactic acid for three days in order to allow their clearing. Then specimens were transferred, dorsum-up, to a small drop of Hoyer's medium on a slide and carefully covered with a small round coverslip. During this process the male genital capsule was gently pressed out of the gaster. After drying, the slides were examined at $100 \mathrm{x}$ and $400 \mathrm{x}$ magnification under the light microscope and morphological characters were determined for species identification according to Pintureau (2011). The morphological classification of pupal parasitoids was based on Goulet and Huber (1993) and a detailed description by Smith (1932). 


\section{RESULTS}

\subsection{ECB flight and parasitation levels}

The ECB pressure varied between northeast Slovenia (Rakičan) and central Slovenia (Jablje). Higher catches were recorded in Rakičan. ECB first occurred in Rakičan at the end of May, early June. In Jablje, ECB was first observed in mid-
June. In both localities two ECB flights were observed, although the two-flight trend was more evident in Rakičan. The first ECB flight peaked from 17-20 June, and the second from 15-20 July. In 2012 in Jablje the first ECB flight was not very distinct. ECB flight waned in August (Figure 1).

\section{ECB flight 2011}

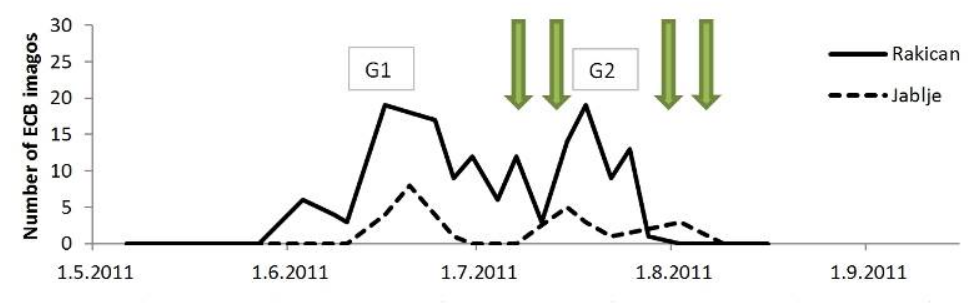

ECB flight 2012

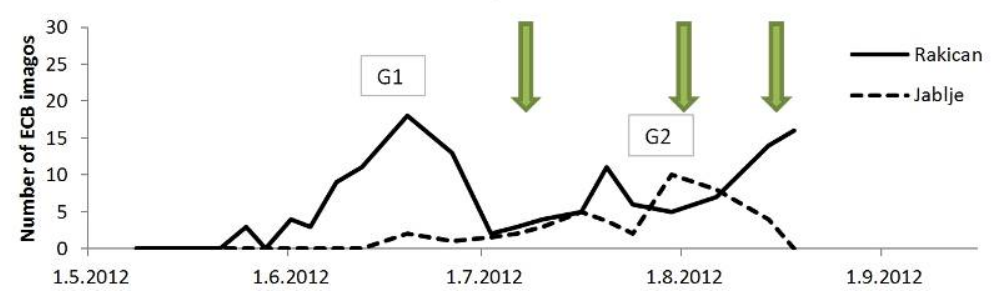

Figure 1: ECB flight in Jablje and Rakičan in 2011 2012. Green arrows show approximate times of ECB egg mass and pupae sampling. G1 or G2 - first or second ECB flight.

During the five years of the survey over 3000 maize plants were inspected for the presence of second generation ECB egg masses. Altogether 84 ECB egg masses were discovered. Five of these 84 egg masses were parasitized, resulting in a percentage parasitism of nearly $6 \%$. Approximately 150 ECB-damaged plants were dissected to obtain potentially parasitized second generation ECB pupae. Approximately 30 pupae were transferred to the laboratory. Two of them were harbouring parasitoids (percentage parasitism: nearly $7 \%$ ). The egg masses were parasitized by Trichogramma brassicae Bezdenko, 1968, whereas the two parasitized pupae were parasitized by Tycherus nigridens Wesmael, 1845. Taxon $T$. nigridens had not been reported previously in Slovenia according to our knowledge.

\subsection{Trichogramma brassicae Bezdenko, 1968}

The parasitized ECB egg masses were typically discovered on the abaxial side of $3^{\text {rd }}$ or $4^{\text {th }}$ maize leaf from stem base up. ECB eggs usually formed aggregates of 20-35 eggs and were located as a single cluster near the central leaf vein. Some parasitized egg masses were completely parasitized, whereas some only partially. After transfer to the lab, minute wasps emerged in 3-5 days from the uniformly black ECB egg masses (Figures 1 and 2). The wasps were minute, ca. $0.9 \mathrm{~mm}$ long, yellow or yellow and black / brown with bright red eyes, short antennae, compact bodies and severely reduced wing venation. Based on morphological characteristics described in Cônsoli et al. (2010), Ferriere and Kerrich (1958), Goulet and Huber (1993), they were classified to the genus Trichogramma. The genus Trichogramma contains more than 200 described species (Pinto, 2006). Mostly they are generalists parasitizing lepidopteran, dipteran, neuropteran and coleopteran egg masses (Querino et al., 2010). 
They are commonly used as an alternative measure to control major agronomical pests via inundative releases (Kölliker-Ott et al., 2004). For more detailed classification to the species level, Pintureau (2011) was used. Based on morphological characteristics of male genitalia the emerged Trichogramma wasps were classified as Trichogramma brassicae (Figure 3). The hymenopteran parasitoid Trichogramma brassicae Bezdenko (Hymenoptera: Trichogrammatidae) was introduced into Western Europe to control ECB more than 40 years ago (Babendreier, 2003b). The introduced strain originates from Moldavia.
Initially it was described under the name T. maidis Pintureau and Voegelé (Pintureau and Voegelé, 1980) and later assigned to be the neotype of $T$. brassicae Bezdenko by Pintureau (1987). Its present day areal extends throughout European mainland, including, but not only, Austria, Belgium, Bulgaria, Germany, France, Italy, Moldova, Romania, Spain, Switzerland, The Netherlands and Ukraine (Fauna Europea, http://www.faunaeur.org/, accessed on June $4^{\text {th }}$, 2015). The species develops idiobiontically inside the egg of the host (Boivin, 2010), where it also overwinters (Stengel et al., 1977).
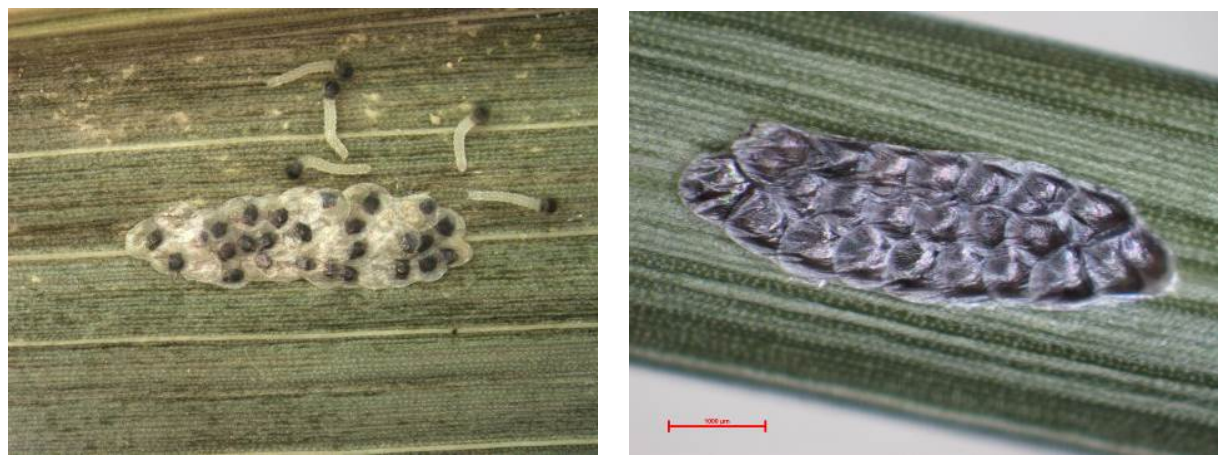

Figure 1: Ostrinia nubilalis (ECB) non-parasitized hatching egg mass (left). Parasitized ECB egg mass (right). Scale bar on the right picture $-1.0 \mathrm{~mm}$. Photos: $\breve{S}$. Modic.
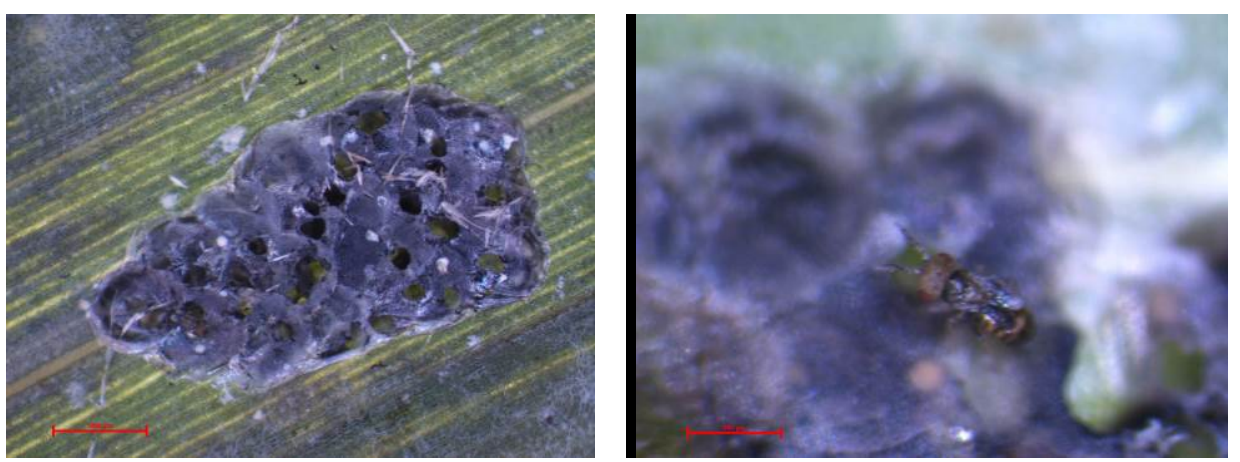

Figure 2: Ostrinia nubilalis parasitized egg mass with Trichogramma brassicae emergence holes (left). Freshly emerged Trichogramma brassicae female (right). Scale bar represents $1.0 \mathrm{~mm}$ on the left and $0.5 \mathrm{~mm}$ on the right picture. Photos: J. Razinger. 

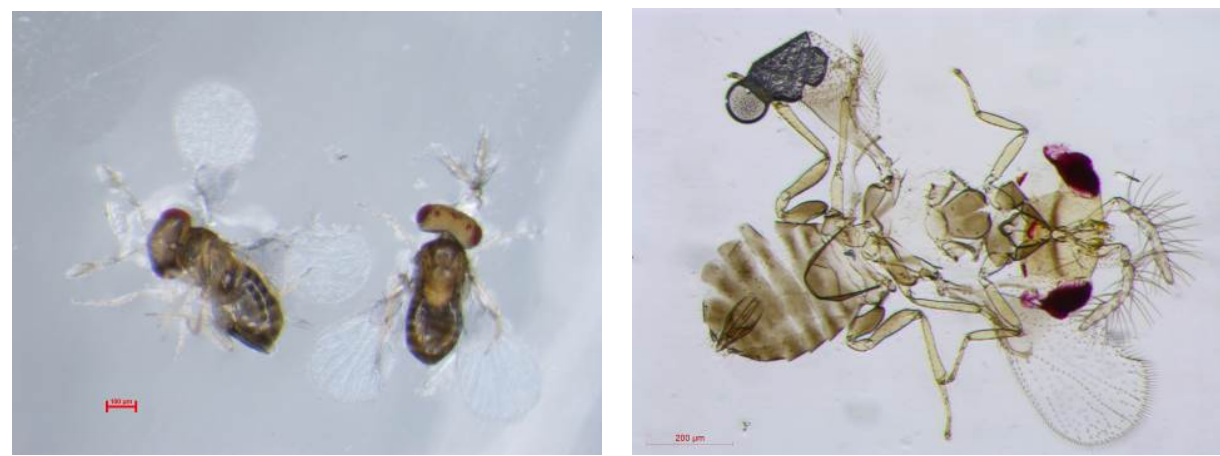

Figure 3: Left picture: Trichogramma brassicae female (left) and male (right). Right picture: microscopic preparation of a Trichogramma brassicae male. Scale bar represents $0.1 \mathrm{~mm}$ on the left and $0.2 \mathrm{~mm}$ on the right picture. Photos: J. Razinger.

\subsection{Tycherus nigridens (Wesmael, 1845)}

The pupae sampled for pupal parasitoid inventarisation were collected from maize plants evidently infested by ECB, exhibiting breakage, holes and / or frass. Most often, the pupae were discovered near the stem base. They were carefully removed from the plants using a Swiss army knife and tweezers. Upon transfer to the lab, the pupae were observed on a daily basis for ECB or parasitoid emergence. When an ECB emerged it was discarded. The emerged parasitoids were classified according to Goulet and Huber (1993) and Smith (1932) to Tycherus nigridens. T. nigridens (Wesmael, 1845) (Hymenoptera: Ichneumonidae; synonym: Tycherus planifrons Wesmael, 1845, Phaeogenes nigridens Wesmael) is an internal solitary parasite which attacks the pupal stage of ECB (Smith, 1932). It prefers 1- and 2-day old pupae, which it perforates with its ovipositor and lays the eggs free in the body cavity of the host (Baker et al., 1949). The earliest definite reference to this species in literature appeared in 1844, when Wesmael first described it

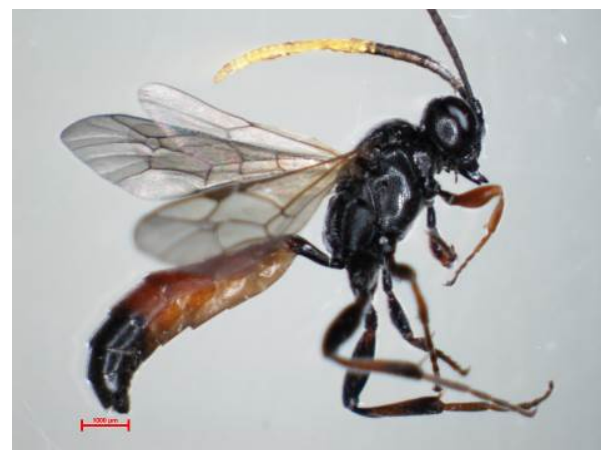

Figure 4: Tycherus nigridens (left) and a detail of forewing venation (right). Scale bar represents $1.0 \mathrm{~mm}$ on both pictures. Photos: J. Razinger.

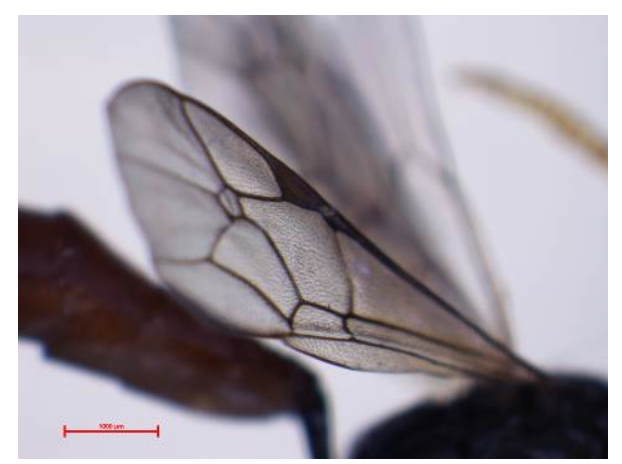

as Phaeogenes nigridens. In addition to the corn borer the only other host from which Tycherus nigridens has been reared is Tortrix pronuboena Hübner (Smith, 1932). The adult is distinguished from the other parasites of ECB by its robust appearance and its rusty red-brown abdomen with black terminal portion. The larva has at least four, maybe five, distinct instars. The adults have long life spans; some females were kept alive at low temperature for 10 months (Smith, 1932). It overwinters as an adult female (Baker et al., 1949). Originally described from Belgium, this species was initially reported from Sweden, Germany, Spain and France (Smith, 1932). Its present day areal includes most of the EU countries, with the exception of the following countries for which no data exists: Albania, Belarus, Bosnia and Herzegovina, Bulgaria, Croatia, Greece, Iceland, Ireland, Kosovo, Latvia, Lithuania, Macedonia, Moldova, Montenegro, Portugal, Serbia, Slovakia, Ukraine and Vojvodina (Fauna Europea, http://www.faunaeur.org/, accessed on June $4^{\text {th }}$, 2015) 


\section{DISCUSSION}

During the five years of the systematic survey we discovered two ECB parasitoid species. ECB egg masses were parasitized by Trichogramma brassicae, already reported in Slovenia by Bohinc et al. (2015), whereas ECB pupae were parasitized by Tycherus nigridens (new finding for Slovenia), with 6 or $7 \%$ parasitation rate, respectively. More effort was invested in searching for egg mass parasitoids ( $>3000$ plants examined). Thus, to be sure of the exactness of $T$. nigridens's observed natural parasitation rate of $7 \%$, we would need to sample a much greater number of pupae.

Trichogramma occurs in all vegetated terrestrial habitats that have been sampled in all six biogeographic regions: Palearctic, Oriental, Nearctic, Neotropical, Afrotropical and Australasian (Querino et al., 2010). T. brassicae was isolated from several host species (Pintureau, 2011). In Slovenia it was first discovered on August 18, 2014, on Mamestra brassicae (Linnaeus, 1758) eggs (Bohinc et al., 2015). However, due to their small size, species of Trichogramma can potentially be transported by wind and intentionally or otherwise, by man from one country to another in a short period of time. Because of this it is often difficult to determine individual species' natural range of distribution (Querino et al., 2010).

Attempts at classical biological control of ECB employing Tycherus nigridens release were performed already in 1924 in the USA when a single colony was released in Massachusetts. Attempts intensified by releasing more numerous parasitoids imported from Europe and Japan, totalling more than $50.000 \mathrm{~T}$. nigridens between years 1926-1933 (Baker et al., 1949). In their report Baker et al. (1949) conclude that the biocontrol program was successful as entomologists were able to recover $T$. nigridens in localities where it was not released in the previous three years, but that more knowledge on the biology of the parasitoid would be needed in order to improve the storage conditions of the adults enabling better synchronization of the releases so the parasitoid would establish broader. Smith et al. (1932) reported that $T$. nigridens was the most effective ECB parasite in Europe with the maximum parasitism rate of $17.5 \%$ recorded in
1930 in the fields around Padova in northern Italy. Factors that may limit its effectiveness as an effective biocontrol agent are the small number of eggs produced by each female; the mortality of some ovarian eggs, especially among hibernating females; the rather long oogenetic period; and the generally unsuitable oviposition conditions in the spring (Smith et al., 1932). Two related Tycherus species are reported in literature as pupal parasitoids of agricultural or forestry pests: cherry bark tortrix, Enarmonia formosana (Scopoli, 1763), an invasive orchard pest in northwest US, is parasitized by Tycherus vagus (Berthoumieu, 1899) (Jenner et al., 2004), whereas Cydia strobilella (Linnaeus, 1758), a Holarctic pest of spruce cones, is parasitized by Tycherus fuscibucca (Berthoumieu, 1901) (Brockerhoff and Kenis, 1996).

T. nigridens represents a new taxon report for Slovenia. However, this taxon has been previously reported from many EU countries, including some of Slovenia's neighbouring countries like Austria, Italy and Hungary, but not Croatia. This fact reveals the problem of reliability of such taxon distribution information, as the real, biological distribution is probably underestimated due to insufficient funding allocated to natural enemy inventarisation studies, especially in countries with a lower gross domestic product per capita. In line with the present Slovenian legislature (Official Gazette of the RS, 83/12, 36/10 40/14, 62/07 and $45 / 06$ ), potential introduction of commercially reared natural enemies and their release can only be done after obtaining concrete evidence on the autochthonous presence of these species as the pests' natural enemies. Thus our study clearly illustrates the need for undertaking systematic surveys of natural enemies of agricultural pests, so that concrete evidence for their autochthonous presence can be confirmed and their introduction possible.

Specific risks exist when releasing large number of Lepidopteran egg parasitoids. Laboratory experiments demonstrated that $T$. brassicae can attack many non-target butterflies including endangered species (Babendreier et al., 2003a). However, non-target butterflies were very seldom attacked under natural conditions in Switzerland (Babendreier et al., 2003b). Besides having 
adverse effects on non-target organisms, inundatively released non-indigenous Trichogramma may compete with locally occurring Trichogramma. Therefore preference should always be given to indigenous strains or species, when developing a new IPM program based on Trichogramma (Herz et al., 2007).

Despite the mentioned risks, one should consider the benefits of parasitoid-based biological control strategies. The released parasitoids do not harm autochthonous population of generalist predators and other beneficial arthropods (Chapman et al., 2009; Zhang et al., 2010); the application has no negative effect on farmers' health; the environment, especially the ground- and surface water is not burdened by pesticides and their breakdown or transformation products (Zhang et al., 2010), and the food or feed is free from insecticide residues.

\section{ACKNOWLEDGEMENTS}

We are indebted to Dr. Jean-Yves Rasplus and MSc. Daniell Rodrigo Rodrigues Fernandes for help with parasitoid classification. We also thank two reviewers for their proactive help in improving the manuscript. This research activity was funded by Slovenian Research Agency's Agrobiodiversity program group (ARRS, P4-0072), and European Union's Seventh Framework Programme projects CropSustaIn and PURE, grant agreements FP7REGPOT-CT2012-316205 and 265865, respectively.

\section{REFERENCES}

Babendreier D, Kuske S, Bigler F, 2003a. Non-target host acceptance and parasitism by Trichogramma brassicae Bezdenko (Hymenoptera: Trichogrammatidae) in the laboratory. Biological Control 26, 128-138. DOI: 10.1016/S10499644(02)00121-4

Babendreier D, Kuske S, Bigler F, 2003b. Parasitism of non-target butterflies by Trichogramma brassicae Bezdenko (Hymenoptera: Trichogrammatidae) under field cage and field conditions. Biological Control 26, 139-145. DOI: 10.1016/S10499644(02)00120-2.

Baker W.A., Bradley W.G., Clark C.A., 1949. Biological Control of the European Corn Borer in the United States. Technical Bulletin 983, 185 pp.

Bohinc T., Schmidt S., Monje J. C., Trdan S., 2015. First record of parasitic wasp Trichogramma brassicae Bezdenko, 1968 (Hymenoptera, Trichogrammatidae) in Slovenia. Acta agriculturae Slovenica 105, 323 - 327. DOI: 10.14720/aas.2015.105.2.15

Boivin G., 2010, Reproduction and Immature Development of Egg Parasitoids. In: Cônsoli, Parra, Zucchi (Eds.), 2010. Egg Parasitoids in Agroecosystems with Emphasis on Trichogramma. Springer Dordrecht. ISBN 978-1-4020-9109-4, 123.
Brockerhoff E.G., Kenis M., 1996. Parasitoids Associated with Cydia strobilella (L.) (Lepidoptera: Tortricidae) in Europe, and Considerations for Their Use for Biological Control in North America. Biological Control 6, 202-214. DOI: $10.1006 /$ bcon.1996.0025

Butrón A., Revilla P., Sandoya G., Ordás A., Malvar R.A., 2009. Resistance to reduce corn borer damage in maize for bread, in Spain. Crop Protection 28, 134-138. DOI: 10.1016/j.cropro.2008.09.007

Carlevaris B., Gomboc S., Milevoj L., 2003. Study on European corn borer (Ostrinia nubilalis Hbn.) on different corn hybrids in Goriška region. Zbornik predavanj in referatov 6 . slovenskega posvetovanja o varstvu rastlin, Zreče, 4. - 6. marec 2003, 176182.

Chapman A.V., Kuhar T.P., Schultz P.B., et al., 2009. Integrating Chemical and Biological Control of European Corn Borer in Bell Pepper. Journal of Economic Entomology 102, 287-295. DOI: $10.1603 / 029.102 .0138$

Cônsoli F.L., Parra J.R.P., Zucchi R.A., 2010. Egg Parasitoids in Agroecosystems with Emphasis on Trichogramma. Springer Dordrecht Heidelberg London New York. ISBN 978-1-4020-9109-4, DOI 10.1007/978-1-4020-9110-0, 479 pp.

European Parliament, 2009. Directive 2009/128/EC of the European Parliament and of the Council. 
http://eur-

lex.europa.eu/LexUriServ/LexUriServ.do?uri=OJ:L :2009:309:0071:0086:EN:PDF

Ferriere Ch., Kerrich G.J., 1958. Handbooks for the identification of British insects. Hymenoptera, 2. Chalcidoidea, section (a). Vol. VIII. Part 2 (a). Royal Entomological Society, London, 44 pp.

Gomboc S., Carlevaris B., Vrhovnik D., Milevoj L., Celar F., 1999. Bionomy of European corn borer (Ostrinia nubilalis Hb.) in Slovenia. Lectures and papers presented at the $4^{\text {th }}$ Slovenian conference on plant protection in Portorož, March 3.-4. Plant Protection Society of Slovenia, Ljubljana, Slovenia, 1999. 459-467.

Goulet H., Huber J.T., 1993. Hymenoptera of the world: An identification guide to families. Agriculture Canada, Ottawa, Canada. ISBN 0-660-14933-8, $680 \mathrm{pp}$.

Herz A, Hassan S.A., Hegazi E., Khafagi W.E., Nasr F.N., Youssef A.I., Agamy E., Blibech I, Ksentini I., Ksantini M., Jardak T., Bento A., Pereira J.A., Torres L., Souliotis C., Moschos T., Milonas P., 2007. Egg parasitoids of the genus Trichogramma (Hymenoptera, Trichogrammatidae) in olive groves of the Mediterranean region. Biological Control 40, 48-56. DOI: 10.1016/j.biocontrol.2006.08.002

Hoffmann M.P., Pitcher S.A., Cheever S.A., Gardner J., Losey J.E., Kuhar T.P., Laub C.A., Youngman R.R., 2006. Efficacy of inoculative releases of Trichogramma ostriniae (Hymenoptera: Trichogrammatidae) against European corn borer Ostrinia nubilalis (Lepidoptera: Crambidae) in field corn. Biological Control 36, 345-349. DOI: 10.1016/j.biocontrol.2005.10.008

Hoffmann M.P., Wright M.G., Pitcher S.A., Garder J., 2002. Inoculative releases of Trichogramma ostriniae for suppression of Ostrinia nubilalis (European corn borer) in sweet corn: field biology and population dynamics. Biological Control 25, 249-258. DOI: 10.1016/S1049-9644(02)00105-6

Jenner, W.H.; Kuhlmann, U.; Cossentine, J.E.; Roitberg, B.D., 2004. Phenology, distribution, and the natural parasitoid community of the cherry bark tortrix. Biological Control 31, 72-82. DOI: 10.1016/j.biocontrol.2004.05.007

Malvar R.A., Butrón A., Álvarez A., Ordás B., Soengas P., Revilla P., Ordás A., 2004. Evaluation of the European Union maize landrace core collection for resistance to Sesamia nonagrioides (Lepidoptera: Noctuidae) and Ostrinia nubilalis (Lepidoptera: Crambidae). J. Econ. Entomol. 97, 628-634. DOI: 10.1603/0022-0493-97.2.628
Meissle M., Mouron P., Musa T., Bigler F., Pons X., Vasileiadis V.P., Otto S., Antichi D., Kiss J., Palinkas Z., Dorner Z., van der Weide R., Groten J., Czembor E., Adamczyk J., Thibord J.-B., Melander B., Cordsen Nielsen G., Poulsen R.T., Zimmermann O., Verschwele A., Oldenburg E., 2010. Pests, pesticide use and alternative options in European maize production: current status and future prospects. J. Appl. Entomol. 134, 357-375. DOI: $10.1111 /$ j.1439-0418.2009.01491.x

Pinto J.D., 2006. A review of the New World genera of Trichogrammatidae (Hymenoptera). Journal of Hymenoptera Research 15 (1), 38-163.

Official Gazette of the Republic of Slovenia: Plant Protection Products Act (UL RS 83/12); Plant Protection Act (UL RS 62/07, 36/10 and 40/14); Rules on the Biological Plant Protection (UL RS 45/06).

Pintureau B., 1987. Systématic évolutive du genre Trichogramma Westwood in Europe. Thesis, Université Paris VII. 311 pp.

Pintureau B., 2011. Les especes europeennes de Trichogrammes (French Edition). InLibroVeritas, France. ISBN 978-2-35209-181-3, 96 pp.

Pintureau B., Voegelé J., 1980: Une nouvelle espèce proche de Trichogramma evanescens: T. maidis (Hym.: Trichogrammatidae). Entomophaga 25, 431-440. DOI: 10.1007/BF02374706

Platner G.R., Velten R.K., Planoutene M., Pinto J.D., 1999: Slide mounting techniques for Trichogramma (Trichogrammatidae) and other minute parasitic Hymenoptera. Ent. News 110 (1), 56-64.

Pons X., Albajes R., 2002. Control of maize pests with imidacloprid seed dressing treatment in Catalonia (NE Iberian Peninsula) under traditional crop conditions. Crop Protection 21, 943-950. DOI: 10.1016/S0261-2194(02)00069-8

Querino R.B., Roberto A.Z., Pinto J.D., 2010. Systematics of the Trichogrammatidae (Hymenoptera: Chalcidoidea) with a Focus on the Genera Attacking Lepidoptera. In: Cônsoli, Parra, Zucchi (Eds.), 2010. Egg Parasitoids in Agroecosystems with Emphasis on Trichogramma. Springer Dordrecht. ISBN 978-1-4020-9109-4, 191-218.

Smith H.D., 1932. Phaeogenes nigridens Wesmael, an Important Ichneumonid Parasite of the Pupa of the European Corn Borer. Washington DC, United States Department of Agriculture, Technical Bulletin 331, 46 pp.

Sobek E.A., Munkvold G.P., 1999. European corn borer (Lepidoptera: Pyralidae) larvae as vectors of

Acta agriculturae Slovenica, 107 - 1, marec 2016 
Fusarium moniliforme, causing kernel rot and symptom less infection of maize kernels. J. Econ. Entomol. 92, 503-509. DOI: 10.1093/jee/92.3.503

Stengel M., Voegelé J., Lewis J.W., 1977. Les Trichogrammes. V.b. Survie hivernale de Trichogramma evanscens Westw. souche moldave et découverte de $T$. cacoeciae Mar. sur pontes d' Ostrinia nubilalis. Ann. Zool. Ecol. Anim. 9 (2), 313-317.

Velasco P., Revilla P., Butrón B., Ordás B., Ordás A., Malvar R.A., 2002. Ear damage of sweet corn inbreds and their hybrids under multiple corn borer infestation. Crop Sci. 42, 724-729. DOI: 10.2135/cropsci2002.0724

Zhang F., Babendreier D., Wang Z.-Y, Il K.S., Zheng L., Pyon Y.C., Bai S.-X., Song K., Ri J.O., Grossrieder M., Kuhlmann U., 2010. Mass releases of Trichogramma ostriniae increase maize production in DPR Korea. Journal Of Applied Entomology 134, 481-490. DOI: 10.1111/j.14390418.2010.01512.x 